\title{
Gelir Getirici Suçlar Temelinde Suç Örgütlerinin Karşı- laştırmalı Analizi: Erzurum Örneği
}

\author{
Dr. Musa KARAKAYA, Dr. Yavuz KAHYA*
}

Gelir Getirici Suçlar Temelinde Suç Örgütlerinin Karşılaştırmalı Analizi: Erzurum Örneği

Özet

Türkiye'de örgütlü suçlara yönelik yapılan soruşturmaların tamamı, kamuoyunda da algılandığı şekliyle, sadece cebir ve şiddet içerikli faaliyet yürüten mafya tipi yapılanmalara ilişkin değildir. Diğer suç tiplerine yönelik bir araya gelmiş örgütsel yapıların da incelenmesi gerekmektedir.

Bu çalışma; Erzurum ilinde, 01.01.2010-31.12.2013 tarihleri arasında, hakkında soruşturma açılmış ve hüküm giymiş organize suç örgütlerinin tamamına ait belge incelemesine dayanmaktadır. Araştırmanın problemi, söz konusu tarihlerde Erzurum'da faaliyet gösteren bu örgütlerin gelir getirici suçlar temelinde birbirlerinden ayrışan yönleridir.

$\mathrm{Bu}$ çalışma ile organize suç örgütlerinin; suç faaliyetleri ve faaliyet alanları, örgüt liderlerinin ve üyelerinin profilleri, örgütlerin sürekliliği, örgüt içi işbölümü, örgütlerin hiyerarşik yapıları yönüyle birbirlerinden nasıl farklılaştıklarını sosyolojik olarak ortaya konulması amaçlanmıştır.

Anahtar Kelimeler: Şiddet, Suç Örgütleri, Sigara Kaçakçılığı, Uyuşturucu Ticareti
Comparative Analysis of Organized Crime Groups based on Income-Generating Crimes: The Case of Erzurum

\section{Abstract}

Majority of the investigations realized in Turkey, about organized crime groups do not apply to mafia groups that include violence in their criminal activities. In this sense, the organizational structures that have come together to commit other types of crimes needs to be revealed.

This study includes investigative works carried out in Erzurum between 01.01.2010-01.12.2013 regarding organized crime groups and based on the document reviews of said investigations. The problem of this study is the differences among Erzurum based organized crime groups regarding their income generating criminal activities.

The aim of this study is determination of the differences among organized crime groups under following subtitles; criminal activities, profiles of leaders and members, continuity, division of labor, and hierarchy.

Keywords: Violence, Organized Crime, Cigarette Smuggling, Drug Dealing

\section{Giriş}

Türk hukuk sisteminde "suç işlemek amacıyla örgüt kurma" ayrı bir suç olarak tanımlanmaktadır. Tanımda işlenmesi planlanan her türlü suç için ön hazırlık ve kolaylaştırıı bir araç olarak 'kurulan örgüt' üzerinde durulmaktadır (TCK, 220. md.). Yasalarda örgüt suçu 'terör örgütü' ve 'çıkar amaçlı suç örgütü' olarak ikiye ayrılmıştır. Buna ilişkin ilk düzenleme 2005 yılında yürürlükten kaldırılan 4422 Sayılı Çıkar Amaçlı Örgütlü Suçlarla Mücadele Kanunu (ÇASÖMK)'dur. Halen örgütlü suçlar ile ilgili yasal dayanak ise 5237 sayılı Türk Ceza Kanunu (TCK) 220. ve 314. Maddeleri ve 3713 sayılı Terörle Mücadele Kanunu'nun (TMK) 10. maddesidir.

* Musa KARAKAYA, Dr., Erzurum il Emniyet Müdürlüğü, musakarakaya@yahoo.com; Yavuz KAHYA, Dr., Erzurum PMYO Müdürlüğü, kahya.yavuz@gmail.com 
Hukuk sisteminde her ne kadar her türlü suç örgütlü olarak işlenebilse ve suç örgütlerine genel olarak TCK 220. madde kapsamında işlem yapılsa da, cebir ve tehdit içeren suç örgütleri ve uyuşturucu madde ticareti yapan suç örgütlerinin adli tahkikatı TMK 10. madde ile yetkili özel savcı ve mahkemelerce yapılmaktadır. Ayrıca bu tip örgütler bu kanunun ilgili maddesi kapsamında değerlendirilmektedir.

Türkiye'de suç örgütlerinin daha çok gelir getirici suç olarak tefecilik, yağma, kumar oynamak için yer ve imkân sağlama, uyuşturucu madde ticareti (-uyuşturucu madde üretimi, nakli ve/veya sokak satıcılığı), sigara kaçakçılığı, emtia kaçakçılığı, fuhuş yaptırmak, ihaleye fesat karıştırma, dolandırıcılık gibi suçları işlediği görülmektedir (UTSAM, 2013). Bu ve benzeri her türlü örgütlü suçun cebir ve şiddet içerikli faaliyetlerde bulunması diğer bir ifade ile mafya tipi bir yapılanmaya dönüşmesi durumunda adli tahkikat doğrudan özel yetkili adli birimlerce yürütülmektedir (TMK 10. md.).

Oldukça karmaşık yapılara sahip olan suç örgütleri, küçük mahalli suç birliği olan sokak çetelerinden sınıraşan organize suç örgütlerine kadar farklı formlarda karşılaşılan bir sosyal olgudur (Kahya ve Sever, 2013). Bunun öncelikli nedeni ülkelerin, hatta her bölge ve yörenin demografik özelliklerinin birbirinden farklı değişkenlere bağlı olarak şekillenmesidir. Böylelikle sosyal bir olgu olan suç örgütleri de bu değişkenlere bağlı olarak yapısal ve niteliksel olarak farklılaşmaktadır. Dolayısıyla tüm dünyaca kabul edilebilecek ortak bir "suç örgütü" tanımının ortaya konulması güçtür (Sands, 2007). Bununla birlikte yapısal olarak işlenen farklı suç tiplerinin bir örgütü diğer örgütlerden ayrıştıran niteliklere sahip olması da bu farklılıkların niteliksel bir başka nedenidir. Literatürde de bu gerçeğe vurgu yapılarak gelir getirici suç ve bu suçu kolaylaştıran diğer suç tiplerinin örgütlerin yapılanmasında ciddi etkisi olduğu tespitinde bulunulmaktadır (Albini, 1971; Mastrofski ve Potter, 1986; Beirne \& Meserschmidt, 2006).

Türkiye'de örgütlü suçlara ilişkin yürütülen pek çok soruşturma, cebir-şiddet unsurunu içeren mafya tipi yapılanmalara yönelik değildir (Karakaya, 2013). Bu anlamda da diğer suç tiplerine yönelik bir araya gelmiş örgütsel yapıların da incelenmesi ve örgütsel yapılar arasında işlenen suç türüne göre farklılaşan yapısal değişikliklerin ortaya konması gerekmektedir. Bu çalışmada 2010-2013 yılları arasında Erzurum'da faaliyet gösteren organize suç örgütlerinin gelir getirici suçlar temelinde birbirlerinden ayrışan yönleri üzerinde durulmuştur. Örgütlere ait belgeler suç faaliyetleri, suçu işledikleri yer, örgüt profili, örgüt içi iş bölümü, örgüt sürekliliği ve hiyerarşisi kriterlerine göre içerik analiziyle değerlendirilmiştir.

\section{Literatür Taraması}

Ulusal ve uluslararası literatürde örgüt yapısına vurgu yapılmak suretiyle temelde 'suç örgütü' veya organize olmuş bir suçluluk yönüyle 'örgütlü suç' ifadelerinin kullanıldığı görülmektedir (Finckenauer, 2001, s. 172; Demir ve Küçükuysal, 2011, s. 243). Örgütlü suç kavramı üzerine niteleyici ve belirleyici çok çeşitli tanımlamalar yapılmışır. Genellikle tanımlarda örgütlü suça açıklama getirilirken olgunun temel prensipleri, içeriği ile ilgili belirtileri, ortak özellikleri, belirgin davranışları ve benzer kavramlardan hangi yönleriyle farklılaştığı üzerinde durulmuştur (Kahya ve Sever, 2013). Bu 
nedenle örgütlü suçun bütün yönlerini içine alan bir tanımlama yapmak kolay değildir (Sever, 2011, s. 185). Bu durum, kavramın çok karmaşık, az çalışımış ve aynı zamanda gizli işlenmesinden dolayı az bilinen, belli-belirsiz bir konu olmasından kaynaklanmaktadır (Finckenauer, 2007, vii).

Literatürde örgüt tanımlamasında zorunlu ve tercihe bağlı olarak belirlenen kriterlerden söz edilmektedir. Bu kriterlerden başlıcaları 'örgüt üyesi sayısı' (Albini, 1971; Maltz, 1976), dikey ve/veya yatay 'örgüt içi hiyerarşi' (Abadinsky, 2010; Conklin, 2010; Grennan ve Britz, 2006; Reuter ve Rubinstein, 1978), 'üyeler arasındaki işbölümü' (Conklin, 2010; Cressey, 1969; Ortmeier, 2013), 'örgütün süreklilik göstermesi' (Abadinsky, 2010; Albanese, 2000; Conklin, 2010; Finckenauer, 2005; Hess, 2009; Ortmeier, 2013; Rhodes, 1984) ve 'örgüt içi kurallar' (Abadinsky, 2010) olarak karşımıza çıkmaktadır.

Bunun yanı sıra diğer bir kısım çalışmalarda ise sadece yapısal özellikler değil aynı zamanda örgütün yürütmüş olduğu faaliyetler üzerinden örgüt tanımlamasına gidildiği de görülmektedir. Örneğin Hellman (1980)'ın çalışmasında örgütlü suç gruplarının faaliyetlerine vurgu yapmak suretiyle örgüt tanımlamıştır. Yazara göre suç örgütleri yasadışı alanda faaliyet gösteren büyük çaplı ve geniş alanda hareket eden organizasyonlardır ve amaçları maddi gelirdir.

Mastrofski ve Potter (1986) çalışmalarında suç örgütleri ile kanun koyucu ve uygulayıcıların etkili bir mücadelede yürütülebilmesi için önceliğin organize suç örgütlerinin faaliyet alanlarının belirlenmesi olduğunu ifade etmektedirler. Yazarlara göre örgütsel yapıların belirlenerek faaliyetlerinin tanımlanması yanlıştır çünkü örgütler yürüttükleri faaliyetlere göre yapılanmaktadırlar. Aynı çalışmada, suç örgütleri ile mücadelede ikincil olarak yerine getirilmesi gereken konunun belirli bir organize suç faaliyetinin tekrar tanımlanması ve tüm resmin ortaya konmasıdır; örneğin uyuşturucu madde ticareti pek çok alt faaliyeti içerisinde barındırmaktadır. Bunlardan bazıları uyuşturucu maddenin üretimi, taşınması, sokaklarda dağıtımı ve kullanımıdır. Suç örgütlerinin bu gibi alt faaliyet alanlarının 'tamamında mı?' yoksa 'bir bölümün de mi?' faaliyet gösterdiğinin belirlenmesi örgütlerin anlaşılabilmesi ve onlarla mücadele edilebilmesi için önemlidir. Çünkü örgütsel yapılar bu alt faaliyetlerine göre de şekillenebilmektedirler. Albini (1971) de suç örgütlerini belirli özelliklere göre değil işledikleri suçlara göre tanımlanması ve tasnif edilmesi gerekliliğini savunmuştur. Suç örgütleri dinamik yapılardır ve işledikleri suçun özelliklerine göre şekillenebilmektedirler. Beirne ve Meserschmidt (2006) de çalışmalarında, örgütlerin işlemiş oldukları suç türüne göre farklı bir yapılanma içerisinde olduğunu ifade etmektedirler.

Örgütlerin yürütmüş oldukları faaliyetler kapsamında yapılmış tanımlamalarda en çok vurgu yapılan kavram ise cebir-şiddet-korku unsurlarının örgüt oluşumu için gerekliliğidir (Abadinsky, 2010; Albanese, 2000; Finckenauer, 2005; Schulte-Bockholt, 2001; Hess, 2009). Örneğin SchulteBockholt (2001) çalışmasında örgütlü suç grubunun birincil amacının zenginlik ve güce ulaşmak olduğunu ifade ederken, örgütlerin buna ulaşabilmek için kolaylaştırıcı bir etken olarak toplum veya zamana göre değişen, tehdit ve şiddet içeren yöntemleri kullandığını belirtmiştir. Desroches (2007)'in çalışmasında da yine şiddet olgusuna vurgu yapılmaktadır; çalışmaya göre suç örgütü yasadışı hizmet veya eşya ticareti içermekte, birden fazla birey birlikte suç faaliyeti yürütmekte, 
ekonomik gelir elde etmek amacıyla suç işlenmekte ve işlenen suçun kolaylaştırılması maksadıyla yolsuzluk ve/veya şiddet içeren suç türleri kullanılmaktadır.

Her ne kadar örgütler işlemiş oldukları suçu kolaylaştırmak ve korku oluşturarak devamlılıklarını sağlamak amacıyla cebir ve şiddet içeren suçları işlemiş olsalar da örgütlerin işlemiş oldukları gelir getirici suç tiplerinin de çeşitlilik içinde olduğu görülmektedir. Bir kısım suç örgütleri belirli bir gelir getirici suç üzerine yoğunlaşırken, yine diğer bir kısım suç örgütlerinde ise birden fazla gelir getirici suç tipi işlenmek suretiyle gelir elde edildiği görülmektedir. Bu bağlamda da lanni (1974) suç örgütlerini sosyal sistemin bir parçası olarak görmektedir. Çünkü bu yapılar toplumun "illegal" intiyaçlarını karşılayan yapılardır ve belirli bir "arz-talep" olgusu nedeniyle ortaya çıkmışlardır. Yazar toplumda belirli kesimlerin bir kısım illegal madde veya servis taleplerinin olduğunu vurgulamış ve örgütlerin de bu tarz bireylerin ihtiyacını görmek maksadıyla ortaya çıktığını belirtmiştir ki yazara göre bu kapsamda da örgütü ortaya çıkaran toplumsal ihtiyaçlardır ve işlenen suç tipindeki çeşitlilik illegal toplumsal taleple şekillenmektedir.

Rasyonel Tercih Teorisi perspektifinde kar-zarar hesabı içerisinde çıkar peşinde koşan suç örgütlerini tanımlayan Cressey (1969) de "yüksek kar-düşük risk" olgusuna vurgu yapmaktadır. Yazar, örgütlerin tıpkı illegal bir ticari müessese gibi faaliyetlerinde bu olguyu önemsediklerini vurgulamaktadır. Örgütler zamana ve şartlara göre şekillenen yüksek kar elde edebilecekleri düşük riskli suçlara yönelmek suretiyle gelirlerini artırmaya ve varlıklarını korumaya çalışmaktadır. Mazzitelli (2007)'ye göre suç örgütleri rasyonel kurallara sıkı bir bağlılık içerisinde faaliyet göstermekte, riski en aza indirgeyerek en büyük kazancı elde etmeye çalışmakta ve buna bağlı olarak da işledikleri suç tipleri çeşitlenmektedir.

\subsection{Suç Örgütlerinin Faaliyetleri}

Örgütlerin kurulmasının temelinde haksız kazancın suç işlemek suretiyle elde edilmesi vardır (Beirne ve Meserschmidt, 2006; Conklin, 2010; Cressey, 1969; Hellman, 1980). Bir çalışmada bu olgu, örgütlerin işlemiş olduğu suçlar için "asli suç" olarak tanımlanmıştır (Karakaya ve Karabal, 2012). Beirne ve Meserschmidt (2006) bu suçlara örnek olarak uyuşturucu madde ticareti, fuhuş ve kara para aklamayı örnek vermektedir. Block ve Chambliss (1981)'in örneklemesinde örgütlü olarak işlenebilecek suçlar şantaj, uyuşturucu madde ticareti, fuhuş, kumar oynatma ve tefeciliktir. Falcone (2005)'e göre ise örgütlerin işleyebilecekleri suç türleri dolandırıcilık, hırsızlık, haraç alma ve tehdit gibi suçlardır. Koppen vd. (2010) yapmış olduğu çalışmada örgütlerin işlediği suçları üç kategoriye ayırmıştır; uyuşturucu madde ticareti, dolandırııılık/sahtecilik ve diğer suç türleridir.

Örgütsel yapılar her ne kadar gelir elde etmek maksadıyla belirli suçları işlemekte iseler de işlemiş oldukları suç tiplerinin bir bölümü doğrudan gelir getirici suçlar değildir. Özellikle cebir ve şiddet, bir kııım örgütler tarafından gelir getirici suçu kolaylaştırıcı olarak kullanılmaktadırlar (Albanese, 2000; Finckenauer, 2005; Kenney ve Finckenauer 1995; Lupsha, 1983; Ortmeier, 2013; Rhodes, 1984; Beare, 1996; Desroches, 2007; Schulte-Bockholt, 2001; Hess, 2009). Suç örgütleri "tali suç" olarak da adlandırılan (Karakaya ve Karabal, 2012) bu faaliyetleriyle bireyler ve toplum üzerin- 
de korku oluşturmaktadırlar. Bu şekilde daha kolay gelir elde edebilmekte ve örgütsel gücünü artırmaktadır. Tali suçlara örnek olarak tehdit, yaralama, cinayet, hürriyeti tahdit, mesken veya işyeri dokunulmazlı̆ıını ihlal suçları verilebilir. Ülkemiz yasalarına göre ise, örgüt tarafından yukarıda bahsi geçen ve korku oluşturmak maksadıyla işlenen cebir-şiddet içerikli suçların tespiti halinde bahse konu örgüt yapısı TMK 10. maddesi hükümlerine göre özel yetkili mahkeme ve savcllılarca takip edilmektedir. Cebir ve şiddetin içinde olduğu suçları işleyen örgütler "mafya" olarak da ifade edilmektedir.

Türkiye'de örgütlü suçlara ilişkin yürütülen pek çok soruşturma, cebir-şiddet unsurunu içeren mafya tipi yapılanmalara yönelik değildir (Karakaya, 2013). Bu anlamda da diğer suç tiplerine yönelik bir araya gelmiş örgütsel yapıların da incelenmesi ve örgütsel yapılar arasında işlenen suç türüne göre farklılaşan yapısal değişikliklerin ortaya konması gerekmektedir. Reiss (1988)'e göre suç örgütleri arasındaki farklııkların anlaşılması organize suçlarla mücadelede atılması gereken önemli bir adım olacaktır.

TMK'nın 10. maddesi kapsamında özel yetkili savcılar ve mahkemelerce işlem gören bir diğer örgütsel yapı türü ise uyuşturucu madde ticareti yapan suç örgütleridir. Daha önceki çalışmalarda örgütlü suçun tanımı yapılırken yasadışı faaliyetler vurgulanmış ve "uyuşturucu madde ticareti" bu faaliyet türlerinden birisi olarak ifade edilmiştir (Sellin, 1963; Block \& Chambliss, 1981; Dorn vd. 1998; Ponsaers vd., 2008; Benson ve Decker, 2010; Koppen vd. 2010; Beirne ve Meserschmidt, 2006; Williams, 1998). Yine bu çalışmalarda uyuşturucu ile ilgili faaliyet yürüten örgüt yapısının diğer suç örgütü yapılarından farklı olduğu vurgulanmaktadır. Örneğin, Williams (1998)'a göre uyuşturucu madde kaçakçllı̆̆ yapan örgütlerde belirli bir silsilede dikey veya yatay hiyerarşik yapı söz konusu değildir. Örgüt üyeleri daha bağımsızdır ve bağımsız hareket etmektedirler. Benson ve Decker (2010) de çalışmalarında uyuşturucu madde ticareti yapan örgütlerde farklı bir yapılanmanın olduğunu ifade etmişler ve uyuşturucu madde ticareti yapan örgütlerde diğer bir kısım örgütlerden farklı olarak dikey bir hiyerarşik yapılanmadan daha çok, yatay bir hiyerarşik yapıya sahip olduklarını belirtmişlerdir.

Suç örgütlerinin yürütmüş olduğu faaliyetlere ilişkin değerlendirmelerde bulunan bir başka çaIışmada da, eşya ticareti ile ilgili faaliyette bulunan örgütlerin diğer suç faaliyetlerinde bulunan örgüt yapılarından ayrıştıklarını vurgulamaktadır (Hagan, 2010; Kenney ve Finckenauer, 1995; Desroches, 2007; Cressey, 1969; Winslow ve Zhang, 2008). Emniyet Genel Müdürlüğü Kaçakçlık ve Organize Suçlarla Mücadele Daire Başkanlığı tarafından hazırlanan yılık faaliyet raporlarına göre, diğer kaçak eşya türlerine kıyaslandığında da bir eşya kaçakçılığı faaliyeti olan sigara kaçakçılığının ülkemizde artan bir şekilde yaygınlaştığı görülmektedir. lanni (1974), Cressey (1969) ve Mazzitelli (2007)'nin çalışmalarında belirtmiş oldukları arz-talep ve düşük risk-yüksek kar olgularına bağlı olarak da suç örgütlerinin bu alanda faaliyet göstermeye başladığı değerlendirilmektedir. Çünkü sigara kaçakçılığı ile mücadele eden birimlerde çalışan uygulayıcılar ile yapılan mülakatlarda pek çok uyuşturucu madde ticareti yapan birey ve örgütün sigara kaçakçılığı yapmaya başladığı vurgulanmaktadır (Acaroğlu, 2013). Bu gerçekliğin nedeni "risk" faktörüdür. Sigara faaliyetini yürütürken tespit edilmeleri ve yakalanmaları halinde uyuşturucu madde ticaretine göre çok daha az cezai 
müeyyideye çarptırımaları ve yakalanmamaları halinde ise önemli miktarda gelir elde etmeleri konusu belirtilmiştir.

\section{Yöntem}

Bu araştırmanın problemi, 2010-2013 yılları arasında Erzurum'da faaliyet gösteren organize suç örgütlerinin gelir getirici suçlar temelinde birbirlerinden ayrışan yönleridir. Araştırmanın kapsamı, 2010-2013 yılları arasında Erzurum ili genelinde faaliyet gösteren organize suç örgütleri ile sınırlıdır. Bu çalışma ile amaçlanan ise Erzurum'da işledikleri suçlar nedeniyle haklarında kolluk tarafından işlem yapılmış ve mahkemece haklarında hüküm verilmiş suç örgütlerinin birbirlerinden nasıl farklılaştıkları konusunda tespitte bulunarak bu tür suçların önlenmesine yönelik çalışmalara katkı sağlamak ve bu alanda yazan, düşünen tüm bilim insanlarına yarar sağlayarak sonraki çalışmalara ön olmaktır.

Araştırmada organize suç örgütleri açısından cevap aranan sorular şunlardır:

a) Organize suç örgütleri, suç faaliyetleri ve faaliyet çevreleri bakımından farklılaşmakta mıdır?

b) Suç faaliyetlerine göre örgüt lider ve üye profilleri değişmekte midir?

c) Örgütlerin sürekliliği her bir örgüt tipinde nasıldır?

d) Örgütlerin kendi içlerindeki işbölümü işledikleri suça göre farklılık arz etmekte midir?

e) Örgüt tiplerinin hiyerarşik yapıları nasıldır?

Çalışmanın literatür taramasında da detaylı bir şekilde anlatılığı üzere örgütlerin tanımlamasında araştırmacıların ve profesyonellerin birleştiği ortak bir tanım bulunamamakta ve bunun bir kısım nedenlerinin olduğu belirtilmektedir (Albini, 1971; Mastrofski ve Potter, 1986; Beirne ve Meserschmidt, 2006; Sands, 2007). Bu çalışmada ise Türk hukuk sisteminde kabul gören örgüt tanımlaması temelinde incelemelere yer verilecektir. Türkiye'de örgütlü suçlarla mücadelede kullanılan tanım, uluslararası sözleşmelerden, 5271 sayılı Türk Ceza Kanunu ve kanun gerekçesinden ve Yargıtay içtihatlarından hareketle Türk hukukunda yerini almaktadır. Buna göre örgütlü suçun oluşması için aşağıdaki kriterler aranmaktadır (Öztürk vd., 2012; 5237 Sayılı TCK'nın 220. Maddesi ve Gerekçesi; Yargıtay 8. Ceza Dairesi 2005/341 E. 2005/2011 K., Yargıtay 8. Ceza Dairesi 2004/11065 E. 2007/517 K.);

- Üye sayısı (en az üç kişi)

- Suç işlemek amaç ve kastı

- Suç işlemeye elverişlilik/yetkinlik

- Süreklilik/devamlılık 
- ̇ş bölümü

- Hiyerarşik yapı

Yukarıda belirtilen suç örgütü kriterlerinden ilk üçü araştırmaya konu olan tüm örgütlerde bulunmaktadır. Diğer bir ifade ile Erzurum ilinde faaliyet gösteren örgütlerin tamamının üye sayııının 3 (üç) kişiden fazla olduğu ve birlikte suç işledikleri görülmektedir. Ayrıca suç işlemek amaç-kastı ve suç işlemeye elverişlilik özelliklerinin tüm örgütlerde bulunduğu anlaşılmış ve benzer ilişkilerin değil karşılaştırmalarda farklııkların üzerinde durulacağından yukarıda belirtilen özellikler değerlendirme dışında bırakılmıştır. Dolayısıyla araşıırmaya konu edilen suç örgütlerine ait belgelerde içerik incelemesi, geriye kalan üç kriter;

a) Örgütlerin sürekliliği

b) Örgüt içi işbölümü,

c) Örgütlerin hiyerarşik yapıları ile

literatürde sözü edilen kriterlerden

d) Örgütlerin faaliyet alanları ve suç faaliyetleri,

e) Örgüt liderlerinin ve üyelerinin profilleri,

başılıları altında kategorize edilerek yapılmıştır.

Diğer bir ifadeyle örgütler, sırasıyla suç faaliyetleri ve faaliyet alanları, örgüt liderlerinin ve üyelerinin profilleri, örgütlerin sürekliliği, örgüt içi işbölümü, örgütlerin hiyerarşik yapıları kriterleriyle değerlendirilmiştir. Her bir örgüte ait belgeler bu sınfflandırmalara göre incelenmiş ve bulgulara bu başıklar altında yer verilmiştir.

\subsection{Veriler ve Veri Analizi}

Veri seti, 01.01.2010-31.12.2013 tarihleri arasında, Erzurum Cumhuriyet Başsavcılı̆ınca haklarında soruşturma yürütülmüş ve mahkemece haklarında hüküm verilmiş toplam 12 suç örgütünün tamamına ait mahkeme belgeleridir. Dolayısılla çalışma, araştırmanın temel sorularına yanıt olabilecek nitel verilere dayandırılmıştır.

Bu veriler araştırma sorularına göre sistematik bir şekilde sınıflandırıldıktan sonra 'betimsel ve sistematik nitel analizi' yöntemiyle değerlendirilmiştir. Ayrıca lider ya da operasyon isimleri ile anılan organize suç örgütleri, bu gerçek isimleri ile değil kodlanarak adlandırımıştır. Bu nedenle araştırmaya konu olan örgütler, belgelerde belirtilen 'dosya yılı' ve o yll içerisinde kendi içlerindeki 'sıralama' dikkate alınarak isimlendirilmiştir. Örneğin 2012 yılının tamamında 3 farklı organize suç örgütüne yönelik işlem yapılmış ise bu örgütler işlem tarihi sırasına göre 2012/1, 2012/2 ve 2012/3 olarak adlandırımışlardır. Ardından örgütlere ait veriler bu sıra takip edilerek cevabı aranan araştırma sorularına göre irdelenerek dijital ortamda ayrı bölümlere geçirilmiştir. Böylece her bir soru için açılan dosyada tüm örgütlere ait bilgiler bir araya getirilmiştir. 
Ardından araştırma soruları ekseninde ortaya çıkan bilgiler her bir örgüt tipine ait alt kategorilere ayrılarak betimlenmiştir. Çünkü örgütlerin gelir getirici faaliyetleri ve işledikleri suç tipleri temelinde üç farklı gruba ayrıldığı görülmüştür (Tablo 1). Bunların ilki şiddet içeren eylemleri işleyen mafya tipi örgütleridir. Erzurum'daki mafya tipi örgütler, suç faaliyetlerini kolaylaştıran cebir-tehdit unsuruna dayalı olarak sigara kaçakçılığı dışında uyuşturucu ticareti, tefecilik, yağma ve kumar oynatmak için yer temini suçlarını işlemektedir. Diğer organize suç grupları ise uyuşturucu ticareti ve sigara kaçakçılığı yapan organize suç örgütü tipleridir. Her bir kıstas, sözü edilen üç farklı örgüt tiplerine ait başıılar altında ayrı ayrı değerlendirilmiş, bulgulara ve yorumlara bu başlıklar altında yer verilmiştir.

Tablo 1. Erzurum ilindeki organize suç örgüt tipleri

\begin{tabular}{lc}
\hline \hline Suç Örgütü Tipi & Suç Örgütü \\
\hline & $2010 / 1$ \\
Mafya Tipi Suç Örgütleri & $2011 / 2$ \\
& $2012 / 2$ \\
Uyuşturucu Madde Ticareti Yapan Suç Örgütleri & $2012 / 3$ \\
& $2013 / 2$ \\
& $2010 / 2$ \\
Sigara Kaçakçוlığı Yapan Suç Örgütleri & $2011 / 1$ \\
\hline
\end{tabular}

\section{Araştırmanın Bulguları}

\section{1. Örgütlerin Suç Faaliyetleri ile Faaliyet Alanlarından Kaynaklanan Farklılıklar}

Suç örgütlerinin kurulmasının temelinde suç işlemek suretiyle elde edilen haksız kazanç veya çıkar vardır (Hellman, 1980; Schulte-Bockholt, 2001; Koppen vd., 2010; Desroches, 2007; Lupsha, 1983; Ortmeier, 2013). Mastrofski ve Potter (1986)'e göre de suç örgütleri ile etkin bir mücadelede yürütülebilmesi ve yürütülen mücadelenin anlamlı bir şekilde değerlendirilebilmesi için yapılması 
gereken ilk şeyin 'organize suç örgütlerinin faaliyet alanlarının belirlenmesi' olduğu ifade edilmektedir.

Erzurum ilindeki örgütlerin gelir getirici suç faaliyetlerine baktığımızda beş farklı yasadışı eylemle gelir elde ettikleri görülmektedir. Bunlar tefecilik, yağma, uyuşturucu ticareti, sigara kaçakçılığı ve kumar oynatmaktır (Tablo 2). Bir kısım örgütlerin ise aynı zamanda birden fazla gelir getirici suç alanında faaliyet gösterdiği de tespit edilmiştir. Bunun yanı sıra altı (6) suç örgütünün ise literatürde belirtildiği gibi (Kenney ve Finckenauer 1995; Lupsha, 1983; Ortmeier, 2013; Rhodes 1984) faaliyetlerinde cebir ve tehdit unsurunun yani şiddetin bulunduğu ve bu kapsamda mafya tipi bir yapılanma içerisinde olduğu ya da mafya tipi bir yapıya dönüşüm içerisinde bulunduğu gözlemlenmiştir.

Tablo 2'ye bakıldığında, suç faaliyetleri kapsamında 2010 yılı içerisinde haklarında işlem yapılmış iki örgütün biri kumar oynatmak, yağma ve cebir-tehdit içerikli suç faaliyetinde bulunurken diğeri sadece uyuşturucu madde ticareti suç faaliyetinde bulunmaktadır. 2011 yılındaki beş örgütten ikisinin yine sadece uyuşturucu ticareti yaparak yasadışı gelir elde ettikleri anlaşılmaktadır. Bunlardan biri sadece sigara kaçakçılığı yaparken son ikisi ise yağma ve cebir-tehdit içerikli şiddet suçlarını işledikleri ve bunlardan birinin ayrıca uyuşturucu ile ilgili suç faaliyetlerinde bulundukları tespit edilmiştir.

Tablo 2. Örgütlerin Suç Faaliyetleri

\begin{tabular}{|c|c|c|c|c|c|c|}
\hline $\begin{array}{l}\text { Suç } \\
\text { Örgütleri }\end{array}$ & Tefecilik & $\begin{array}{r}\text { Kumar } \\
\text { Oynatmak }\end{array}$ & Yağma & $\begin{array}{c}\text { uşturucu } \\
\text { Madde } \\
\text { Ticareti }\end{array}$ & $\begin{array}{r}\text { Sigara } \\
\text { Kaçakçılığı } \\
\end{array}$ & $\begin{array}{r}\text { Cebir-Tehdit } \\
\text { Unsuru }\end{array}$ \\
\hline 2010/1 & & $x$ & $x$ & & & $x$ \\
\hline $2010 / 2$ & & & & $x$ & & \\
\hline $2011 / 1$ & & & & $x$ & & \\
\hline $2011 / 2$ & & & $x$ & & & $x$ \\
\hline $2011 / 3$ & & & $x$ & $x$ & & $x$ \\
\hline $2011 / 4$ & & & & & $x$ & \\
\hline $2011 / 5$ & & & & $x$ & & \\
\hline $2012 / 1$ & & & & $x$ & & \\
\hline $2012 / 2$ & $x$ & $x$ & $x$ & & & $x$ \\
\hline $2012 / 3$ & $x$ & & & & & $x$ \\
\hline $2013 / 1$ & & & & & $x$ & \\
\hline $2013 / 2$ & $x$ & & $x$ & & & $x$ \\
\hline
\end{tabular}


2012 yllındaki üç suç örgütünden biri sadece uyuşturucu madde ticareti yaparken, diğer ikisi şiddeti kolaylaştırıcı unsur olarak diğer suç faaliyetlerinde kullanan mafya tipi oluşumlardır. Bu oluşumlardan biri tefecilik üzerine yoğunlaşırken diğeri sigara ve uyuşturucu içerikli suçlar dışında tüm suçlarda şiddeti kullanmaktadır. Son olarak 2013 yılındaki iki örgütün biri sadece sigara kaçakçılığı suçunu işlemektedir. Diğeri ise mafya tipi bir örgüt olarak tefecilik ve yağma suç faaliyetlerinde bulunmaktadır.

Örgütler, ağırlıkı olarak faaliyette bulundukları suç alanları dikkate alınarak sınıflandırıldığında üç (3) farklı türden örgüt faaliyet yapısı karşımıza çakmaktadır. Bu örgüt yapılarının; cebir ve şiddet içeren faaliyetleri nedeniyle mafya tipi suç örgütleri (2010/1, 2011/2, 2012/2, 2012/3, 2013/2), uyuşturucu madde ticareti faaliyetleri nedeniyle uyuşturucu madde ticareti yapan suç örgütleri (2010/2, 2011/1, 2011/5, 2012/1) ve sigara kaçakçוlığı faaliyetleri nedeniyle sigara kaçakçılığı yapan suç örgütleri (2011/4, 2013/1) olduğu görülmüştür. 2011/3 olarak adlandırılan suç örgütünde her ne kadar cebir-tehdit unsurunun varlığı tespit edilmişse de örgütün cebir-şiddet içerikli eylemlerinin örgütün son dönemlerinde geliştiği ve mafya tipi bir yapıya dönüşüm içerisinde olduğu gözlenmiştir. Çoğunlukla uyuşturucu madde ticareti alanında faaliyeti yürütmesi nedeniyle uyuşturucu madde ticareti yapan örgütler kısmında değerlendirmeye tabi tutulmuştur.

Suç faaliyetleri ve suçu işledikleri çevre kriterine göre birbirlerinden farklılık göstermekte olan üç farklı organize suç grubuna ait bulgu ve yorumlara, aşağıda belirtilen başılılar altında ayrı ayrı yer verilmiştir.

\subsubsection{Mafya Tipi Suç Örgütlerinde Suç Faaliyetleri ve Faaliyet Alanları}

Mafya tipi suç örgütlerinin coğrafi olarak faaliyet gösterdikleri alanlara bakıldığında beş farklı suç örgütünün her birinin Erzurum il sınırlarında suç faaliyetlerinde bulundukları ancak 2010/1 adlı örgütün ise aynı zamanda Antalya ilinde de faaliyet gösterdiği gözlenmiştir. Bu örgütlerin gelir getirici suç faaliyeti olarak da tefecilik, kumar oynanması için yer temini ve yağma suçlarını işlenmiş oldukları görülmektedir (Tablo 2).

Mafya tipi olan bu örgütlerin tamamında cebir-tehdit unsurunu içeren yardımcı suç faaliyetleri işledikleri gözlenmektedir. Cebir-şiddet içerikli bu faaliyetlerin genel olarak tehdit, kasten yaralama, hürriyeti tahdit, mesken ve işyeri masuniyetinin ihlali ve mala zarar verme suçlarından oluştuğu görülmüş, korku unsurunun örgütler tarafından etkin bir şekilde kullanıldığı tespit edilmiştir.

Örgüt üyelerinin cebir ve tehdit içeren suçları gelir getirici suçları kolaylaştırmak amacıyla işledikleri anlaşılmaktadır. Ancak örgütün varlığının kendilerinde oluşturduğu güven duygusunun etkisi ile örgüt üyelerinin bireysel olarak cebir-şiddet içerikli eylemlerde de bulundukları görülmektedir.

Örgütlerin yol açtığı mağduriyetlerin hem gelir getirici suç faaliyetlerinden hem de kolaylaştırıcı suç faaliyetlerinden dolayı oluştuğu ve ayrıca daha çok suç mağdurlarının şikâyetleri sayesinde suçla mücadelenin şekillendiği tespit edilmiştir. Suç örgütleri ile ilgili şikâyet edenlerin sayılarına bakıldığında; 
- 2010/1 adlı örgütte 11 müşteki,

- 2011/2 adlı örgütte 17 müşteki,

- 2012/2 adlı örgütte 12 müşteki,

- 2012/3 adlı örgütte 14 müşteki ve

- 2013/2 adlı örgütte 5 müşteki olduğu görülmektedir.

Her ne kadar bütün soruşturmalarda şikâyetçilerin olduğu görülse de soruş̧urmaların tamamında mağdur olduğu halde şikâyetçi olmak istemeyenlerin de varlığından söz edilmektedir. Yapılan içerik analizinde mağduriyeti kolluk tarafından tespit edilmiş olan kişilerin bir kısmı mağduriyetini kabul etmek istememekte bir kısmı da mağduriyetini kabul etmekle birlikte şikâyetçi olmayacaklarıı ifade etmişlerdir. Bu durumun örgütlerin korkutucu gücünden kaynaklandığı değerlendirilmektedir.

Örgütlerin gelir getirici suç faaliyetleri arasında yer alan tefecilik suçunun, anlık nakit paraya ihtiyacı olup da çoğu zaman borç alabileceği kimse bulunmayan veya bankalardan kredi çekebilecek şartları taşımayanlara yüksek faizler karşılı̆ı verilerek gerçekleştiği görülmektedir. Belirli bir miktar sınırlaması olmaksızın, piyasadaki faiz oranlarından çok daha yüksek oranda ve kısa vadeli borç verilmektedir. Borç alan mağdurların örgüt üyeleri ile bire bir görüştükleri ve bu şekilde örgüt yapısının geneline ilişkin gizliliğin korunduğu anlaşılmaktadır. Ancak mağdurun borcunu ödeyemez duruma gelmesiyle örgütün diğer üyeleri ortaya çıkmakta ve kişi üzerinde baskı oluşturmaktadırlar.

İ̧̧erik analizi çalışmasında karşılaşılan bir diğer konu ise tefecilik suçunun çoğu zaman diğer bir gelir getirici suç tipi olan nitelikli yağma suçunu doğurduğudur. Tefecilik mağdurlarıın borçlanırken taşınır-taşınmaz mallarına noterden şerh koydurulması, zorla elde edilmesi ve senet imzalatılması şeklinde ortaya çıkan bu suç kapsamında tehdit, hürriyeti tahdit, mesken masuniyetinin ihlali suçlarının kolaylaştıııı suç olarak işlendiği anlaşılmıştır.

Diğer bir gelir getirici suç faaliyeti ise kumar oynatmak için yer temininde bulunmalarıdır. Mafya tipi suç örgütleri, kumar mağdurlarının oyunlarından doğan borçlarının tahsil edilmesi amacıyla tefecilik suçunun ve devamında nitelikli yağma suçlarının iş̧lendiği tespit edilmiştir. Aynı şekilde hem tefecilik, hem nitelikli yağma hem de kumar oyunlarını içeren suç faaliyetlerinde cebir ve şiddet içerikli eylemlerde bulundukları görülmektedir. Özellikle kumar oyunlarıı suç faaliyetlerini yürüttükleri alanda tek elde toplamak gayretiyle cebir ve tehdit unsurlarını kullandıkları anlaşılmaktadır.

Bir diğer tespit ise yağma suçunun mafya tipi örgütlerin tefecilik ve kumar oynatmaktan dolayı mağdur edilen kişilerden alacaklarını tahsil etmek için başvurdukları bir yöntem olduğudur. Ayrıca 2010/1 ve 2011/2 adlı suç örgütlerinin gerçekleştirmiş oldukları yağma suçunun, haraç alma ve çek senet tahsilâtçוı̆̆ı yapma faaliyetleri ile ortaya çıktı̆ı da tespiti yapılan bir diğer konudur. 
Musa KARAKAYA | Yavuz KAHYA

\subsubsection{Uyuşturucu Madde Ticareti Yapan Suç Örgütlerinde Suç Faaliyetleri ve Faaliyet Alanla-} rı

Uyuşturucu madde içerikli suçlar genel olarak dört (4) temel faaliyete bağlı olarak dört (4) temel birey grubunu bünyesinde barındırmaktadır (TUBIM, 2012). Bunlar;

- uyuşturucu madde üreticilerini,

- uyuşturucu madde nakli yapan kuryeleri,

- uyuşturucu madde satışını yapan sokak satıcılarını ve

- uyuşturucu madde kullanıcılarını

kapsamaktadır.

Çalışmada uyuşturucu madde ticareti yapan suç örgütlerinin (2010/2, 2011/1, 2011/3, $2011 / 5,2012 / 1$ ) genel olarak uyuşturucu madde ticaretini sokak satışı şeklinde gerçekleştirdikleri görülmüştür. Dolayısıyla diğer uyuşturucu madde içerikli suçlar olan uyuşturucunun üretimi ve büyük miktardaki uyuşturucu madde nakline yönelik faaliyetlere çalışmada rastlanmamıştır.

Uyuşturucu madde ticareti yapan örgütlerinin tamamı Erzurum ili sınırlarını faaliyet alanı olarak belirlemişlerdir. Bu örgütlerin suç faaliyeti ise uyuşturucu madde kullanıcısının talebi üzerine uyuşturucu madde satışıdır. Örgütlerin ticaretini yaptığı uyuşturucu maddenin çeşidi çok büyük bir oranla (\% 97) esrar maddesidir.

Örgütler suç faaliyetleri sırasında kolluk birimlerine yakalanmamak için bazı detaylara dikkat ettikleri tespit edilmiştir. Özelikle uyuşturucu ile mücadele eden birimlerin teknik uygulamalarına takılmamak için çoğu örgüt üyesi telefon kullanmamaktadır. Telefon kullananlar ise uyuşturucu madde konulu görüşmelerini şifreli ifadeler kullanarak yapmaya özen göstermektedirler. Örgüt üyelerinin kolluk birimlerinin takibine karşı aldıkları diğer bir önlem ise uyuşturucu madde satışını gecekondu mahallelerinde, dar, karışık ve sakin sokak aralarında yapmalarıdır. Özellikle 2010/2, 2011/3, 2011/5 adlı uyuşturucu ticareti yapan suç örgütlerinin mahalle yapılanmasının olduğu ve uyuşturucuyu çoğunlukla kolluk takibi ve tespitinin güç olduğu kendi mahallelerinde yaptıkları anlaşılmaktadır.

Uyuşturucu madde ticareti yapan örgütlerin tamamı, yasadışı maddeyi Erzurum ili dışında başka bir ilden ve farklı kaynaklardan temin etmektedirler. Uyuşturucu maddenin temin edildiği yerler Van, Hakkâri, Ağrı, Diyarbakır ve Bingöl illeridir.

Uyuşturucu ticareti yapan bu örgütler, mafya tipi suç örgütlerindeki gibi gelir getirici suçları ve bu suçları kolaylaştırıı tehdit-şiddet içerikli unsurlarla ilgilenmedikleri, ancak aynı suç faaliyetiyle ilgilenen grupların bölgedeki hâkimiyeti kendi lehlerine çevirebilmek adına yer yer silahlı kavgalara girdikleri tespit edilmiştir. Bu şekilde kendi aralarında silahlı kavga çıkan örgüt (2011/3, 2012/1) sayısı ikidir. 
Ayrıca uyuşturucu ticareti yapan beş örgüt içerisinde 2011/3 adlı örgütün, mafya tipi bir yapılanmaya dönüşüm içerisinde olduğu ve zorla uyuşturucu madde satmaya çalıştığı, uyuşturucu madde satın almak istemeyenleri darp ederek paralarını gasp ettiği böylece yağma suçunu işlediği görülmektedir.

\subsubsection{Sigara Kaçakçııı̆ı Yapan Suç Örgütlerinde Suç Faaliyetleri ve Faaliyet Alanları}

2011/4 ve 2013/1 adlı suç örgütlerinin gelir getirici suç faaliyeti olarak sigara kaçakçılığı suçunu işlemiş olduğu görülmektedir. Sigara kaçakçılığı diğer suç örgütlerinin işlemiş oldukları suçlara cezai müeyyidesi bakımından kıyasla daha az risk taşıyan bir suç faaliyetidir. Hatta uygulamalarda görüldüğü üzere sigara kaçakçılığı yapan kişiler çoğunlukla gözaltına alınmadan tutuksuz olarak yargılanmaktadırlar.

Sigara kaçakçılığı yapan suç örgütleri aynı uyuşturucu madde ticareti yapan suç örgütleri gibi tek bir gelir getirici suç faaliyeti ile ilgilenmektedirler. Örgütler genel olarak Ağrı veya Van ilinde bulunan kaynak konumundaki bireylerden genellikle 10.000 paket üzerinde miktarlarda kaçak sigarayı Erzurum iline ve/veya batısındaki illere nakledilmek üzere geçişini yapmakta, depolamakta ve satmaktadırlar. Aynı şekilde tablacı konumunda olan ve kaçak sigaranın perakende satışını yapanlara kaynaklık etmektedirler. Sigara kaçakçılığı yapan örgütler nakillerde yöntem olarak kiralık araç firmalarının araçlarını kullanmakta, kısmen de üyelerinin araçlarını kullanmaktadırlar. Kiralık araç firmalarının, sigara kaçakçılığında kullanılacağını bile bile araçlarının kullanılmasına müsaade ettikleri görülmektedir. Bunun nedeni olarak bu araçlar kaçakçılıkta kullanılırken yakalandığında suçu işleyen kişilere ait olmadığından el konulamamasıdır. Dolayısıyla örgütler bu tip araçları kullanarak mücadele birimlerine karşı yakalanma ve ceza alma riskini daha da azaltmaktırlar. Bu durumun oluşmasında etkili olan hukuki düzenlemeye bakıldığında; 5237 sayılı TCK'nın 54. maddesi hükümlerine göre kaçakçılıkta kullanılan araç, ancak suçu işleyen şahsa ait olması durumunda el konulabildiğine işaret etmektedir.

Örgütler, sigara kaçakçılığı faaliyetinde gözaltı işlemi uygulanmaması nedeniyle suçta adeta profesyonelleşmekte ve kolluk önlemlerine karşın yeni tedbirler geliştirmek suretiyle faaliyetlerine devam etmektedirler. Kendi aralarında yaptıkları görüşmelerde şifreli dil kullanarak önceden belirledikleri terminolojiyle konuşmakta ve böylelikle kolluk tarafından uygulanabilecek teknik takibe karşı da önlem almaktadırlar. Sigara taşımacılığı sırasında telefonun kapalı olması veya yeni alınan telefon ve telefon hatları kullanılmak suretiyle taşımacılık yapılması da kullanılan diğer önlemler arasında bulunmaktadır. Kolluğun suç önleme faaliyetlerine karşı şüphelilerce geliştirilen bir diğer önlem ise "eskort" olarak ifade edilen öncü araç kullanımıdır. Sigara yüklü araç/araçlar muhtemel polis uygulamalarından bu eskort araçlar sayesinde haberdar olmaktadır. Bu çalışmada kullanılan öncü araç sayısının taşımacılığı yapılan sigara miktarına göre üçe kadar çıkabildiği tespit edilmiştir. Kullanılan bir diğer kaçaklık yöntemi ise gizli bölmeli araçlarla kaçak sigara taşımacılı̆ıdır. Böylelikle dıştan bakıldığında tespiti güç olan gizli bölmelerle, kolluğun güvenlik tedbiri aldığı yerlerde, uygulamalara karşı önlem alınmaktadır. 
Musa KARAKAYA | Yavuz KAHYA

\section{2. Örgütlerin Liderler ve Üye Profillerinden Kaynaklanan Farklılıklar}

Örgüt liderinin ve üyelerinin profilleri kriterine göre birbirlerinden farklılık göstermekte olan üç farklı organize suç grubuna ait bulgu ve yorumlara, aşağıda belirtilen başlıklar altında ayrı ayrı yer verilmiştir.

\subsubsection{Mafya Tipi Suç Örgütlerindeki Lider ve Üye Profili}

Çalışmada, mafya tipi suç örgütlerinin büyük bir kısmının aile fertlerinden oluştuğu görülmektedir. 2010/1 adlı örgüt dışındaki diğer mafya tipi suç örgütlerinin lider ve yönetici kadroları aile büyüklerinden oluşmaktadır. Bu örgütlerde lider profiline bakıldığında diğer örgüt üyelerinden yaşça büyük oldukları anlaşılmıştır. 2010/1 adlı örgütün ise mahalle arkadaşlı̆ı üzerinden yapılandığı ve geliştiği; kısmen aile fertlerinden üyelerin de örgüt içinde yer aldığı hatta küçük kardeşin örgüte lider olurken büyük olan kardeşin de liderden talimatlar aldığı görülmektedir. Bu örgütteki lider profiline bakıldığında ise en çok suç geçmişi olanın lider olduğu karşımıza çıkmaktadır. Bu özelliği ile diğer örgüt üyeleri üzerinde korku ve baskı unsuru oluşturmaktadır. Mafya tipi örgütlerde liderlerin suç faaliyetlerindeki konumu genellikle yönlendirme ve tavsiyelerde bulunma şeklindedir; yapılan yönlendirmeler doğrultusunda suçlar örgüt üyelerince işlenmektedir.

Mafya tipi suç örgütlerinde üyelerin tamamı 20 yaş üzeri bireylerden oluşmaktadır. Çoğunluğun (\% 84) ise 20-40 yaş aralığında olduğu görülmektedir. Örgüt üyelerinin \% 75'inde suç geçmişlerinin olduğu görülürken, üyelerin sabıkalarının 6136 sayılı kanun (Ateşli Silahlar, Bıçaklar ve Diğer Aletler Hakkındaki Kanun)'a muhalefet, tehdit ve kasten yaralama suçlarının en yoğun şekilde işlenmiş suç türlerinden olduğu tespit edilmiştir. Bu grupta bulunan örgüt üyelerinin Erzurum'da ikamet ettikleri (\% 90 üzeri), Erzurum doğumlu (\% 80 üzeri) ve Erzurum nüfusuna kayıtlı (\% 80 üzeri) oldukları görülmektedir.

\subsubsection{Uyuşturucu Madde Ticareti Yapan Suç Örgütlerindeki Lider ve Üye Profili}

Uyuşturucu madde ticareti yapan suç örgütlerinde, örgüt içerisindeki "liderlik ve yöneticilik" konumu bireyin uyuşturucu maddeyi temin edebilme kabiliyetine göre şekillenmektedir. Uyuşturucu maddeyi toplu olarak satan bireyler tanımadıkları şahsa uyuşturucu madde satışı yapmamakta veya kalitesiz uyuşturucu madde satışı yapabilmektedirler. Bu kapsamda da şahısların "kaliteli" uyuşturucu maddeyi toplu olarak temin edebilmeleri onların örgüt içerisindeki etkinliğini artırmaktadır. Yöneticiler genellikle lidere yakın olan kişilerdir. Lider ve yöneticilerin zaman zaman sokakta bizzat uyuşturucu madde satışı yaptıkları görülmekle birlikte daha çok temin edilen uyuşturucu maddenin sokak satışını yapan üyelere dağıtma konusunda rol aldıkları ve satılan uyuşturucudan komisyon aldıkları anlaşılmaktadır.

Örgüt üyelerinin yaş durumuna bakıldığında çoğunlukla (\% 70) 16-25 yaş aralığında oldukları anlaşılmaktadır. Sadece iki kişi 35 yaş üzerindedir. Örgütlerin lider ve yöneticilerinin örgüt üyelerine kıyasla daha yaşlı ve suç geçmişleri bakımından daha çok sabıkalı oldukları tespiti yapılan bir diğer husustur. Örgüt üyelerinin \% 75'inin daha önceden suç kaydı bulunduğu ve suç kayıtları incelendi- 
ğinde hırsızlık, kasten yaralama ve 6136 sayılı kanuna muhalefet suçunun sırasıyla en fazla işlenen suç türleri olduğu görülmektedir. Bu grupta bulunan örgüt üye ve yöneticilerinin büyük oranda Erzurum'da ikamet eden (\% 90 üzeri), Erzurum doğumlu (\% 80 üzeri) ve Erzurum nüfusuna kayıtlı (\% 80 üzeri) şahıslardan oluştuğu görülmektedir.

\subsubsection{Sigara Kaçakçılığı Yapan Suç Örgütlerindeki Lider ve Üye Profili}

Sigara kaçakçıllğı yapan suç örgütlerinde de bir önceki örgüt grubu ile benzer şekilde, bireylerin örgüt içindeki konumlarının yürütülen suç faaliyetindeki etkinliklerine göre şekillendiği görülmektedir. Örgütlerin lider ve yöneticileri suç unsuru olan "kaçak sigara” temin edebilme kabiliyetleri ve yürütülen suç faaliyetindeki etkinliklerine göre örgüt içerisinde nüfuza sahiptir. Örgüt liderleri zaman zaman bizzat suç eşyasının taşınması faaliyetinde bulunmaktadır fakat çoğunlukla suç unsurunun temini ve suç faaliyetinin organize edilmesinde rol almaktadırlar. Böylelikle lider ve yönetici grubu suç organizasyonunda koordinatör rolüyle faaliyet göstermekte ve diğer örgüt üyelerinin üzerindeki etkileri, yürütülen faaliyetle sınırı kalmaktadır.

Sigara kaçakçılığı yapan örgüt üyeleri 18-46 yaş aralığındadır. Büyük çoğunluğunun (\%80 üzeri) 25 yaş üzeri kişilerden oluştuğu görülmektedir. Örgütlere üye olan bu gruptaki kişilerin büyük çoğunluğunun suç geçmişleri bulunmaktadır. İşlenen suç türlerinin büyük bir kısmı kaçakçılık suçlarından oluşmaktadır. Yürütülen faaliyet iller arasında olması nedeniyle örgüt üyeleri \% 50’ye yakın oranda diğer çevre ve uluslararası sınırları bulunan illerde ikamet etmektedir.

\section{3. Örgütlerin Sürekliliği (Devamlılık) Unsurundan Kaynaklanan Farklılıklar}

Örgütlü olarak işlenen bir suçu, iştirak halinde işlenen suçtan ayıran üç özellikten birisi "devamlıık" özelliğidir. İştirak halinde işlenen suçlarda bireyler belirli bir suçu işlemek için bir araya gelmektedir. Diğer bir ifade ile işlenmesi planlanan suçta "konu ve mağdur" itibarı ile somutlaşma mevcuttur, fakat örgüt yapılanmalarında suç işleme kastı varken "konu ve mağdur" itibarı ile somutlaşma yoktur. Örgüt yalnızca belirli bir suçu işlemek için bir araya gelmiş bir grup değildir (Öztürk vd., 2011, 5237 Sayılı TCK'nun 220 md. gerekçesi). Örgütün varlığına ilişkin "süreklilik" kriteri ile ifade edilmek istenen husus, örgütün suç işlememiş olsa bile gerek örgüt üyelerinin daha önce birlikte işledikleri suçlar, gerekse halen örgütlü bir şekilde suç işlemeye devam etme "niyet ve kasıtları"nın bulunmasıdır. Bu anlamda da "süreklilik", suç işlemek amacıyla kurulan örgütün "suç işlemek amacıyla" varlığını sürdürmedeki niyet ve kastıdır, oluşan suç yapısının varlığının devamlılığıdir.

Örgütlerin sürekliliği unsuru kriterine göre birbirlerinden farklılık göstermekte olan üç farklı organize suç grubuna ait bulgu ve yorumlara, aşağıda belirtilen başılılar altında ayrı ayrı yer verilmiştir.

\subsubsection{Mafya Tipi Suç Örgütlerinde Süreklilik}

Örgütler çoğunluğu itibarı ile akrabalık bağlarının kuvvetli olduğu bir birliktelik içerisindedir. Aile ilişkişleri nedeniyle var olan bir süreklilikten bahsedilebilir. Bu özelliğin suç faaliyetlerine de yansıması kaçınılmaz olmuştur. Aynı şekilde kısmen aile ilişkilerine sahip 2010/1 adlı örgütün de sosyal 
Musa KARAKAYA | Yavuz KAHYA

çevre üzerine kurulu ağdan kaynaklı mahalle arkadaşlığından oluşan yapısından dolayı devamlıık unsuruna sahip olduğu anlaşılmaktadır.

Mafya tipi örgütler yürüttükleri gelir getirici faaliyetlerde korku unsurunu aktif bir şekilde kullanmaktadırlar. Bu nedenle "örgütün süreklilig̈i” bu tip örgütsel yapılarda ayrıca bir öneme sahiptir. Süreklilik örgütün gücünün bir göstergesidir. Mafya tipi yapılarda süreklilik olgusunun hem işlenen suçların devamlılı̆ı hem de yapının devamlılığı açısından somut bir şekilde ortaya çıktığı görülmektedir. Suç faaliyetinde kesinti olduğu durumlarda da örgütlerin varlığını devam ettirdiği tespiti yapılan bir diğer konudur.

\subsubsection{Uyuşturucu Madde Ticareti Yapan Suç Örgütlerinde Süreklilik}

Uyuşturucu madde ticareti yapan gruplar diğer suç örgütlerine kıyasla daha genç bireylerden oluşmakta ve çoğunlukla mahalle arkadaşlığı olgusu ile gelişen bir bağlııkla varlıklarını sürdürmektedirler. Bu bağ|lık "arkadaşlık" ile suçta somutlaşmakta ve suç arkadaşlığına dönüşerek kendisini göstermektedir.

Bu grup içerisinde bulunan örgütsel yapıların işlemiş olduğu suçun, uyuşturucunun nakli ve sokakta satışı olmak üzere birbirine bağlı fakat iki farklı aktivite ve suçu, bir başka deyişle iki farklı zorluğu barındırması nedeniyle bireylerin arasındaki bağılığı kuvvetlendirmektedir. Bununla birlikte, suç faaliyetinin (uyuşturucu madde ticareti) kesintiye uğraması ile örgüt mensubu bireylerin arasındaki bağın zayıfladığı ve bu kapsamda da bu tip örgütlerde uyuşturucu içerikli suç faaliyetinin sürekliliğinin örgüt yapısının sürekliliğine çok büyük oranda etki yaptığı belirlenmiştir.

\subsubsection{Sigara Kaçakçılığı Yapan Suç Örgütlerinde Süreklilik}

Sigara kaçakçılığı yapan suç örgütlerinde bütünüyle yürütülen faaliyete odaklı bir birliktelik ve süreklilik olduğu görülmektedir. Örgüt, yürütülen faaliyetin gerçekleştirilişi sırasında bir araya gelmekte ve faaliyetin başarıya ulaştırılması amacıyla birlikteliklerini sürdürmektedirler. Bu kapsamda da bu tip örgütlerde örgütün sürekliliği bütünüyle faaliyetin sürekliliği ve suçtan elde edilen gelirin devamlılı̆ı olarak ifade edilebilmektedir. Yapısal bir süreklilik çok sınırlı düzeydedir ve bu gruptaki örgütlerin faaliyet olarak sürekliliğinden bahsedilebilmektedir.

\section{4. Örgütlerin Kendi İçlerindeki İşbölümünden Kaynaklanan Farklıııklar}

“İ̧̧ bölümü" kriteri birden fazla şahıs tarafından yerine getirilmesi gereken suç faaliyetlerine ilişkin olarak örgüt üyeleri arasındaki görev paylaşımını ifade etmektedir. Her ne kadar 5237 Sayılı TCK'nın 220. maddesi metni ve gerekçesinde bu kritere ilişkin herhangi bir hüküm yer almasa da Yargıtay'ın içtihatlarında bu kriterin örgütün yapısında bulunması gerekli olduğu ifade edilmektedir (Yargitay 8. Ceza Dairesi 2005/341 E., 2005/2011 K., Yargitay 8. Ceza Dairesi 2004/11065 E., 2007/517 K.). İçtihatlarda iş bölümü "sürekli ve disiplinli işbirliği" ve "işbölümü" olmak üzere iki farklı şekilde ifade edildiği görülmektedir. 
Örgüt içi işbölümü kriterine göre birbirlerinden farklılık göstermekte olan üç farklı organize suç grubuna ait bulgu ve yorumlara, aşağıda belirtilen başlıklar altında ayrı ayrı yer verilmiştir.

\subsubsection{Mafya Tipi Suç Örgütlerinde İşbölümü}

Mafya tipi suç örgütlerinin yürüttüğü faaliyetler genel itibarı ile birden fazla kişinin birlikteliğini ve yürütülen faaliyette disiplinli işbölümünü gerektirmektedir. Bu durum suç mağduru olan kişide korku hissi oluşturmasının yanında örgüt içerisindeki bireylerin kendilerine olan güveninin artmasını ve örgüt bilincinin oluşmasını sağlamaktadır. Böylelikle örgüt üyeleri suça katılmak suretiyle örgüte bağ|lığını göstermekte ve fedakârlıkta bulunmaktadır. Örneğin yürütülen tefecilik faaliyetinde şahısla ilk irtibat kuran, borç veren ve borcu tahsil için cebir-tehdit unsurlarını kullanan şahıslar farklı örgüt üyeleri olabilmekte fakat yürütülen faaliyet bir bütün ve organize bir suç faaliyeti olarak anlaşılmaktadır. Tüm örgütlerin üyeleri alınan talimat ve yönlendirmeler doğrultusunda hareket ederek benzer yöntemler kullanmak suretiyle sonuca ulaşmaya çalışmaktadır. Bireyler yerine getirdikleri sorumluluk karşılığında doğrudan bir gelir beklememekte, elde edilen kazanç örgütün kazancı olarak görülmektedir.

\subsubsection{Uyuşturucu Madde Ticareti Yapan Suç Örgütlerinde İşbölümü}

Uyuşturucu madde ticareti yapan örgütlerde işbölümü suçun gerektirdiği iş paylaşımındaki sorumluluğun yerine getirilmesi şeklinde ortaya çıkmaktadır. Örgüt üyeleri yerine getirdikleri sorumlulukları örgüt üyesi olmalarından daha çok belirli bir gelir getirici faaliyetten faydalanmak için yerine getirmektedir. Örneğin uyuşturucu madde naklinde kuryelik yapan şahıs nakledilen uyuşturucudan pay veya nakil ücreti almak suretiyle işlemiş olduğu suçun mükâfatını hemen almaktadır. Sokakta uyuşturucu madde satışı yapan bireyler ise bundan belirli bir komisyon elde etmekte olduğu için bu suçu işlemektedirler.

\subsubsection{Sigara Kaçakçıı̆ı̆ı Yapan Suç Örgütlerinde İşbölümü}

Sigara kaçakçılığı yapan suç örgütlerinde de örgüt içi işbölümünün işlenen suçun başarı ile sonuçlanması için yapılan görev paylaşımına göre şekillendiği görülmektedir. Suç faaliyetinin tamamlanması ile sorumluluğunu yerine getiren örgüt üyeleri maddi karşılığını almaktadır. İş bölümü suç faaliyetinin her biri için ayrı ayrı önceden tanımlanmaktadır. Bu nedenle sabit nitelikte yapısal bir işbölümü değil her bir faaliyet için yeniden tanımlanan daha esnek bir işbölümünden bahsedilebilir.

\section{5. Örgütlerin Hiyerarşik Yapılarından Kaynaklanan Farklılıklar}

Genel olarak bir topluluk içerisinde bulunan bireyler arasındaki ast-üst ilişkisi olarak tanımlanan "hiyerarşi" kelimesi, Türk hukuk sisteminde örgütün yapısı tanımlanırken örgütün bir özelliği olarak vurgulanmıştır. Yapılan tanımlamada, örgüt üyeleri arasındaki ilişkinin soyut bir birliktelikten daha çok "hiyerarşik" özellikler içerdiği vurgulanırken örgüt hiyerarşisinin "gevşek bir nitelik" taşıyabileceği de ayrıca ifade edilmiştir (5237 sayılı TCK'nın 220. maddesi gerekçesi). Gevşek nitelikli hiyerarşi ile dikey, katı bir ilişki yerine yatay ve daha esnek bir ilişkiden söz edilirken yinede yapısal olarak lider, yönetici ve üyelerden oluşan rol dağılımından söz edilmektedir. Bu hiyerarşik ilişkinin örgüt içerisindeki fonksiyonu ise örgütün üyeleri üzerinde kontrol gücünü sağlamasıdır. 
Örgüt hiyerarşisi kriterine göre birbirlerinden farklılık göstermekte olan üç farklı organize suç grubuna ait bulgu ve yorumlara, aşağıda belirtilen başlıklar altında ayrı ayrı yer verilmiştir.

\subsubsection{Mafya Tipi Suç Örgütlerinde Hiyerarşi}

Bu grupta yer alan suç örgütlerinin tamamında hiyerarşik bir yapının varlığına ilişkin somut göstergeler bulunmaktadır. Örgütlerin tamamında "katı" ve "dikey" bir hiyerarşinin varlı̆ından söz edilebilmektedir. Aslında bir bakıma mafya tipi suç örgütlerinde katı hiyerarşi, bu tip yapıların olmazsa olmazı gibidir. Çünkü örgütler ciddi sorumluluk ve dikkat gerektiren suç faaliyetleri yürütmekte, korku faktörünün etkisi ile suç faaliyetlerinde başarı sağlayabilmektedirler ki bu nedenle emir komuta zincirinin oluşturulması bir gerekliliktir.

Bununla birlikte, örgütler içerisindeki hiyerarşik yapılarda bazı farklılıklar da mevcuttur. 2011/2, 2012/2, 2012/3 ve 2013/2 adlı örgütlerde, aile üyeleri ile başlayan bir örgütsel yapı vardır ve örgüt hiyerarşisi bu yapı temelinde ortaya çıkmaktadır. Bu örgütlerde ailenin en büyüğü örgütün de lideridir ve örgüt liderine yalnızca örgüt lideri olmasından dolayı saygı gösterilmemekte, aynı zamanda ailenin en büyüğü olması nedeniyle de çekirdek kadrosu aynı aileye mensup örgüt üzerinde söz sahibi olmaktadır. Ancak 2010/1 adlı örgüt, bu yönüyle diğer örgütlerden farklıdır. Mahalle arkadaşlı̆ı temelinde başlayan bu yapı zamanla hiyerarşik bir yapı halini almıştır. Örgüt içerisinde kısmen aynı aileye mensup bireyler bulunsa da "aile büyüklüğü" örgüt hiyerarşisinde önemli bir faktör değildir; örneğin 2010/1'in yöneticisi olan şahıs 2010/1'in liderinin abisidir ve "yaşça büyük olan yönetici" kendisinden 7 yaş küçük olan kardeşinden talimat alabilmektedir.

Örgütlerin tamamında örgüt liderlerinin örgüt içerisinde önemli düzeyde ağırlıklarının olduğu görülmektedir. Fakat aynı örgüt içerisindeki yöneticilerin örgüt içerisindeki konumlarında farklılıklar gözlemlenmektedir. Bazı örgüt yöneticilerinin örgüt içerisinde "ikinci adam" konumunda olurken, bir kısım örgüt yöneticileri yalnızca belirli sorumlulukları olduğu veya örgüt liderinin ailesinden olmanın getirmiş olduğu ayrıcılıktan faydalanan bireyler olduğu değerlendirilmektedir.

\subsubsection{Uyuşturucu Madde Ticareti Yapan Suç Örgütlerinde Hiyerarşi}

Çalışmaya konu örgütler üzerinde yapılan incelemede, bu suç örgütü tipinde katı bir hiyerarşik yapının varlığına ilişkin bulguların çok zayıf olduğu görülmüştür ve her beş örgüt için de ancak "gevşek" ve "yatay" bir hiyerarşinin varlığından söz edilebilmektedir. Örgüt lideri ve yöneticilerinin, örgüt içerisindeki etkinliği ve verdikleri talimatlar yalnızca yürütülen faaliyetle sınırlıdır. Örgüt liderlerinin daha çok koordinasyon faaliyeti yürüttükleri görülmektedir.

Örgütlerin bazılarında (2010/2, 2012/1), örgüt liderinin örgüt üyeleri üzerinde hâkimiyet kurmaya çalıştığı görülmekte ve talimatlar vermek istedikleri anlaşılmaktadır. Ancak içerik analizinden yönetici ve üyelerin örgüt liderinden korkmadıkları ve böyle durumlarda örgüt mensupları arasında kavgaya varan boyutlarda tartışmalar yaşandığı tespit edilmiştir. Mahalle yapılanmasının olduğu örgütlerde (2011/1, 2011/3, 2011/5) örgüt lideri ve yöneticilerinin "mahallenin abisi" konumunda bulunan şahıslar olduğu anlaşılmaktadır. Örgütlerin tamamında, lider konumunda bulunan şahısla- 
rın ticareti yapılan uyuşturucu maddeyi toplu halde temin eden şahıslar oldukları, yönetici konumunda bulunan şahısların örgüt içerisinde bulunan diğer şahıslar üzerinde "abi" konumlarıyla etkili oldukları, lider ve yöneticilerin bazı olaylarda bizzat uyuşturucu madde satışı yaptıkları fakat onları örgüt üyelerinden ayıran en başta gelen vasıflarının uyuşturucu madde temin edebilme kabiliyetlerinin olduğu gözlemlenmiştir.

\subsubsection{Sigara Kaçakçılığı Yapan Suç Örgütlerinde Hiyerarşi}

Sigara kaçakçוlığı yapan suç örgütlerinde hiyerarşik yapı, yürütülen suç faaliyeti temelinde ortaya çıkmaktadır. Bu tip örgütlerde katı bir hiyerarşinin varlığı görülmezken gevşek hiyerarşik yapıdan söz edilebilmektedir. Örgüt lideri ve yöneticileri "kaçak sigara” temininde etkin olan bireylerdir ve bu onları diğerlerinden bir adım öne çıkartmaktadır. Bu nedenle yürütülen suç faaliyetinin liderleri konumunda rol almaktadırlar. Liderler bazı olaylarda bizzat suç faaliyeti içerinde bulunmuş olsalar da suçtaki temel sorumlulukları koordinatörlüktür. Bu örgütlerde suç faaliyetinin sona ermesi ile birlikte hiyerarşik oluşumun da sonlandığı görülmektedir. Lider konumundaki şahısların yalnızca yürütülen suç faaliyeti sırasında, yönlendirme olarak da algılanabilecek talimatlarla örgüt üyelerine yol gösterdikleri görülmektedir.

\section{Genel Değerlendirme}

Türkiye'de suç örgütlerinin; güç, iktidar ve para denkleminde en çok tefecilik, yağma, uyuşturucu/sigara/emtia kaçakçılı̆̆ı, fuhuş, ihaleye fesat karıştırmak, dolandırıcılık gibi suçları işledikleri görülmektedir (UTSAM, 2013). Bu anlamda Erzurum ili örneğinde yapılan bu çalışmada da benzer bir sonuca ulaşılmıştır. Bu çalışmayla 2010-2013 yıllarını içine alan süre zarfında, Erzurum ilinde faaliyet gösteren suç örgütlerinin gelir getirici suçlar olarak tefecilik, kumar oynamak için yer ve imkân sağlama, yağma, uyuşturucu madde ticareti ve sigara kaçakçılı̆̆ suçlarını işledikleri görülmüştür. Bu örgütler her ne kadar gelir elde etmek maksadıyla belirli suçları işlemekte iseler de tefecilik, kumar oynamak için yer temin etmek ve yağma gibi suçları kolaylaştırmak için cebir ve şiddet içerikli eylemlerde bulundukları görülmüştür. Dolayısıyla Erzurum özelinde örgütlerin gelir getirici faaliyetleri ve işledikleri suç tipleri temelinde üç farklı grupta; a) mafya tipi suç örgütleri, b) uyuşturucu madde ticareti yapan suç örgütleri ve c) sigara kaçakçılığı yapan suç örgütleri olarak sınıflandırılabilmektedir. Ayrıca tüm örgüt üyelerinin cinsiyetlerinin erkeklerden oluştuğu görülmüştür.

Türk hukuk sistemindeki örgütlü suç kriterlerine göre mafya tipi suç örgütlerinin faaliyet alanları değerlendirildiğinde; örgütlerden birinin ayrıca Antalya ili ile bağlantılı olmak üzere tümünün Erzurum ilinde faal oldukları anlaşıımıştır. Suç faaliyetleri olarak da tefecilik, kumar oynanması için yer temini ve yağma gibi suçları işledikleri ve bunun için cebir-şiddet içerikli tehdit, kasten yaralama, hürriyeti tahdit, mesken ve işyeri masuniyetinin ihlali ve mala zarar verme suçlarını gelir getirici suçları kolaylaştırmak amacıyla işledikleri tespit edilmiştir.

Bu gruptaki örgütlerin eleman profiline bakıldığında ise örgütlerin yapılanmasında sosyal çevre ve hemşehrilik ağlarından daha çok ailevi birlikteliklerin baskın olduğu değerlendirilmektedir. Özellikle lider ve yöneticiler, ailenin yaş̧̧a büyük ve ileri gelenlerinden; diğer üyeler ise ailenin büyükle- 
rine itaat eden daha küçük yaştaki bireylerinden oluşmaktadır. Mafya tipi suç örgütlerinde üyelerin tamamı 20 yaş ve üzeri bireylerden ve tamamına yakını ise Erzurumlulardan oluşmaktadır. Bireylerin yaklaşık 3/4'ünün suç kaydı bulunmaktadır. Daha önce işledikleri suçlar ise 6136 sayılı kanuna muhalefet, tehdit ve kasten yaralama suçlarıdır. Bu örgütlerin faaliyetlerindeki devamlılığın ana unsuru aile ilişkilerindeki kuvvetli bağlardır. Ayrıca mafya tipi suç örgütlerinde örgütün devamlılığı korku unsurunun etkisini de sürekli kıldığından kendileri için var oluş kaynağıdır. Yapısal devamlılığına bağlı olarak korku sürekli kılınmazsa örgütlerin gücü o oranda azalmaktadır. Yürütülen faaliyetlerde disiplinli bir görev takibi ve işbölümü olduğu görülmüştür. Bu durum örgüt içerisindeki bireylerin kendilerine olan güvenini arttırmakta ve örgüt bilincinin oluşmasını sağlamaktadır. Örgütlerin hiyerarşik yapılarına bakıldığında ise dikey ve katı bir yapılanma gözlenmekte ve mafya tipi bu suç örgütlerinin ana karakteristik özelliğinin yinelendiği değerlendirilmektedir.

Uyuşturucu madde ticareti yapan suç örgütlerinin faaliyet alanları ve suç faaliyetleri değerlendirildiğinde ise Erzurum ili genelinde ve büyük oranda esrar satışı şeklinde gerçekleştiği görülmektedir. Uyuşturucu maddeler çevre illerden temin edilmektedir. Örgüt elemanlarının profillerine baktığımızda ise daha çok Erzurumlu, genç ve sabıkalı bireylerin uyuşturucu ticaretinde rol aldıkları anlaşılmaktadır. İşbölümleri aynı zamanda elde edecekleri kar oranının belirlenmesinde etkilidir. Yasadışı maddeyi temin edenin, sokakta satışını yapanın ve aracıların aldıkları komisyon bu görev dağılımına göre farklılaşmaktadır. Bu tip örgütlerde işbölümüne paralel olarak gevşek ve yatay bir hiyerarşiye rastlanmıştır. Kesinlikle mafya tipi örgütlerdeki gibi katı bir ast-üst ilişkisi mevcut değildir. Birbirleriyle görev paylaşımında bir önem sıralaması oluşmuştur. Örneğin yasadışı maddeyi temin eden ile sokakta satış yapanın sosyal çevre ve tanıdık bildik ağı ister istemez örgüt üyeleri arasında değer sıralamasını da belirlemektedir. Dolayısıyla her aktör, kendine ait alandaki nüfuzu sayesinde örgüt içi hiyerarşik yapıda bir öneme sahip olmaktadır.

Son olarak sigara kaçakçılığı yapan suçörgütlerinin faaliyette bulundukları alan ve suç faaliyetleri değerlendirildiğinde; faaliyetin ceza alma riskinin diğer suç örgütlenmelerine kıyasla oldukça düşük olduğu görülmektedir. Erzurum ili sigara kaçakçılığında daha çok transit il olarak görülmektedir. Aynı zamanda ilde kaçak sigara satışından dolayı hedef iller içerisinde yer almaktadır. Ayrıca bu gruptaki örgütler, mücadele birimlerine yakalanmamak için araçsal ve mekansal anlamda farklı yöntemler kullanmaktadırlar. Örneğin yasadışı maddeleri kiralık araçlarla taşımakta; telefon görüşmelerine dikkat etmektedirler. Sigara kaçakçılığı yapan örgütlerin uyuşturucu ticareti yapan örgütlerdekine benzer bir profile sahiptir. Lider, yönetici ve üyeler faaliyet içerisindeki rollerinden kaynaklanan nüfuz alanına göre belirginleşmektedir. Grup üyeleri arasında 18 yaş üstü gençler bulunmasına karşın bunların tamamına yakınının 25-46 yaş aralığındaki erkeklerden oluştuğu anlaşılmaktadır. Ayrıca tamamına yakınının suç geçmişleri bulunmakta ve sabıkalı hale gelmelerindeki nedenin kaçakçılık suçu olduğu tespit edilmiştir. Ancak diğer suç tiplerinde olduğu kadar sigara kaçakçılığı yapanların memleketleri Erzurum değildir. Bu tip suç örgütlerindeki elemanların yaklaşık yarısı Erzurum'da ikamet eden, doğan ya da nüfusuna kayıtlı olan kişilerden oluşmuştur. Bunun en önemli nedeninin sigara kaçakçılı̆ı̆ıda Erzurum'un kaynak il değil de transit il olmasından kaynak- 
lanmaktadır. Örgüt elemanları arasında esnek bir yapılanma ve işbölümü mevcuttur. Faaliyet temelinde bir devamlılıktan söz edilebilir. Ayrıca uyuşturucu ticareti yapan örgütlerin hiyerarşisine benzer bir tarzda gevşek-yatay bir hiyerarşiye sahiptirler.

\section{Sonuç ve Öneriler}

Bu çalışma ile suç örgütlerinin ulusal ve uluslararası ölçekte olduğu kadar bölgesel hatta mahalli alanda da oldukça karmaşık yapılar oluşturabildikleri görülmüştür. Bu sosyal görüntünün farklı değişkenlere bağlı olarak birbirlerinden ayrıştıkları anlaşılmaktadır. Farklılıkların ana nedeni ise örgütlerin tercihte bulunduğu gelir getirici faaliyetlere göre işleyişinin ve yapılanmasının değişime uğramasıdır.

Örgütlerin oluşumunda hangi değerlerin etkin olduğu bu tür yapılan çalışmalarla tespit edilebilmektedir. Bunun için hukuki tanımlama önemlidir. Ancak her örgüt farklı eylem, farklı profildeki eleman kaynağı ve motive unsurlarına göre farklı sosyal görüntüler vermektedir. Dolayısıyla örgütlerin faaliyette bulundukları alanın derinlemesine araştıııması gerekmektedir.

Verilerden elde edilen ampirik bilgiler rasyonel tercih teorisi ışığında değerlendirildiğinde; suç örgütleri, suç faaliyetlerini belirlerken az risk ve çok gelir denkleminde tercihte bulunmaktadırlar. Bu tercihe verilen önem, aynı zamanda organize suç örgütlerini birbirinden ayıran niteliklerini de belirginleştirmektedir. Örgütler, cebir ve şiddet içeren ve kanunlara göre sonucu oldukça ağır cezalar gerektiren faaliyetlerden kaçınmaktadır. Buna rağmen az da olsa mafya tipi olarak tanımlanabilecek bu tür örgütlerle karşılaşılmıştır. Ayrıca uyuşturucu madde ticareti faaliyetleri nedeniyle uyuşturucu madde ticareti yapan suç örgütleri ve sigara kaçakçוlı̆̆ı faaliyetleri nedeniyle sigara kaçakçılığı yapan suç örgütleri de görülmüştür. Dolayısıyla örgütlerin suç faaliyetleri bakımından kesin bir biçimde birbirlerinden ayrışan yönleri olduğu anlaşılmaktadır. Çünkü her örgüt belirli bir suç türünde uzmanlaşarak diğer suçlara uzak kalmaktadır.

Bu bağlamda suç örgütlerine yönelik politikaların aşağıdaki öneriler doğrultusunda geliştirilmesi gerektiği değerlendirilmektedir:

1. Uluslararası, ulusal ve bölgesel/mahalli alanda oluşumunu tamamlayarak suç işleyen her bir örgütün ayrı ayrı motivasyon değerlerinin bilinmesi gereklidir. Suçla mücadelenin parçaları olan her bir kurum ve kuruluş, sadece kendi bulunduğu yerden örgütlü suç olgusunu değerlendirmeyi bırakıp bütüncül sosyolojik bir bakış açısıyla durumu sorgular hale gelmelidir. Çünkü uluslararası, ulusal, bölgesel olarak faaliyetlerini yürüten örgütlerde olduğu gibi belirli il ya da mahallede yasadışı işlerden gelir elde eden örgütler, varlıklarını ve faaliyetlerini sürdürebilmeleri açısından farklı değişkenlere bağıı olarak yapılanmaktadırlar.

2. Bu çalışmada Erzurum ilindeki suç örgütü tiplerinden sigara ticareti ve uyuşturucu kaçakçıllğında olduğu gibi, maddenin üretimi, paketlenmesi ve nakli başka başka yerlerde gerçekleşip, sadece Erzurum ve benzeri illere getirilmesi ve satışı ile ilgilenen suç örgütlenmeleri incelenmiştir. Dolayısıyla devam eden büyük parçanın küçük bir uzantısının resmedildiği bu çalışmayla suç örgütleriyle etkin mücadelenin ancak kaynağına ilişkin olursa daha kesin ve net sonuçlar 
elde edilebileceği anlaşılmaktadır. Her bir suç örgütünün faaliyeti sadece Erzurum gibi lokal ölçekli dar bir alanda işlenmemektedir. Diğer bir ifade ile belirtilen suç faaliyetlerinin ana maddesinin yetiştirilmesi, temini, nakli, koordinasyonu, satışı, her biri ayrı ayrı profesyonellik gerektirdiğinden mücadelede sadece belirli bir alanda sıkışıp kalınmamalıdır. Bu nedenle güvenlik politikalarının çok boyutlu ve geniş perspektifle oluşturulması gerekmektedir. Özellikle suçun kaynağına yönelik mücadelenin önemi büyüktür. Suçun kaynağı sınır dışında ise sınır ve kıyı bölgelerine yönelik mücadele edilmesinin önemi dikkate alınmalıdır.

3. Erzurum ölçeğinde yapılan bu çalışma göstermiştir ki; suç örgütlerinin oluşumunda aile ve sosyal çevrenin etkisi büyüktür. Ne yazık ki suç, suçun işlenişi ve karın çok/riskin az oluşu sosyalleşme kurumlarının temelleri olan aile, akran grubu ve okulda öğrenilmektedir. Birey olumsuz sosyal davranışı bu kurumlardan edinmektedir. Bu nedenle Erzurum ve benzer yerlerde olumlu sosyal davranışların hayatın en temel yapısı olan ailede kazandırılması için çalışmaların genişletilmesine intiyaç vardır. Bu amaçla aile ile ilgili sivil toplum örgütlenmeleri desteklenmeli ve bilimsel araştırma yapan akademisyenler teşvik edilmelidir.

4. Örgütlerin yol açtığı mağduriyetlerin hem gelir getirici suç faaliyetlerinden hem de kolaylaştırıcı suç faaliyetlerinden dolayı oluştuğu görülmekte ve daha çok suç mağdurlarının şikâyetleri sayesinde suçla mücadele şekillendirilmektedir. Suç örgütleri ile ilgili şikâyet edenlerin sayılarına bakıldığında; mağdur olduğu halde şikâyetçi olmak istemeyenlerin yanında oldukça düşük kaldığı anlaşılmaktadır. Bu durumun örgütlerin korkutucu gücünden kaynaklandığı değerlendirilmektedir. Bu nedenle suçla mücadelede başarıyı tüm zamana yayabilmek için mağdurların bu algılarına yönelik gerek fiziki gerek psikolojik koruyucu destek programları geliştirilmelidir.

5. Ayrıca bu tür suç örgütlerinin faaliyetlerinin öğrenilmesinde sadece mağdurların şikayeti değil diğer kamu-özel kurum ve kuruluşlarının da yardımı da istenmelidir. Bu konuda nasıl bir süreç içerisinde kime (3N1K) başvuru yapabileceği ile ilgili topluma yön verecek süreç eğitimi diğer kamu kurum ve kuruluşu personeline verilmelidir. Bu anlamda farkındalık arttırıcı çalışmalar yapılmalıdır.

6. Suç örgütleriyle mücadele sırasında teknik araçlarla dinleme, izleme ve gizli tanık gibi delillendirme ye yönelik hukuka uygun kullanılan tedbirlere karşın, örgütlerin önlemler aldığı ve giderek profesyonelleştikleri görülmektedir. Örneğin sigara kaçakçוlığında nakliyede kullanılan araca el konulmasını önlemek amacıyla kiralık araçlarla taşıma yapılmaktadır. Bu tür suçu kolaylaştırıcı unsurlara yönelik yapılan mücadele, dolaylı olarak suç örgütleriyle mücadeleyi de kolaylaştıracak mahiyettedir.

7. Örgütlerin tamamı Erzurum'da faaliyet göstermekte ancak bir örgütün Antalya ilinde de faaliyetleri bulunmaktadır. Profiller incelendiğinde; sigara kaçakçılığı ile ilgilenen suç örgütlerindeki elemanların yaklaşık yarısı, diğerlerinde ise tamamı Erzurumlu, genç ve erkek bireylerden oluşmaktadır. Bu benzerlikler yanında örgüt faaliyetlerine bakıldığında sigara kaçakçılığı ve uyuşturucu ticareti yapan suç örgütleri ile mafya tipi suç örgütü arasında hiyerarşik anlamda 
önemli bir fark vardır. Bu nedenle mafya tipi suç örgütleri, daha gevşek ve yatay hiyerarşiye sahip kaçakçılık faaliyetleriyle ilgilenen suç örgütlerinden farklı olarak ele alınmalı ve güvenlik strateji ve politikaları bu özelliğe göre belirlenmelidir.

Sonuç olarak suç örgütleri ile etkin bir mücadelede yürütülebilmesi ve yürütülen mücadelenin anlamlı bir şekilde değerlendirilebilmesi için yapılması gereken ilk adım organize suç örgütlerinin faaliyet alanlarının belirlenmesidir. Bu amaçla çalışmada gerçekleştirilen analizler ve elde edilen bulgular, hem kanun koyucuları ve güvenlik stratejilerinin belirleyicilerini, hem de uygulayıcı birimleri destekleyici niteliktedir. Suç örgütlerinin faaliyetleri, suç işledikleri alanları, hukuki olarak örgütün oluşumunda önemli olan hiyerarşi, devamlıık, iş bölümü ve benzeri niteliklerinin detaylı ele alınması gerektiği düşünülmektedir. Bu şekilde daha etkin ve kolay bir mücadele stratejisi belirlenebileceği saptanmıştır.

\section{Kaynaklar}

3713 Terörle Mücadele Kanunu (TMK)

5237 Sayılı Türk Ceza Kanunu (TCK)

5237 Sayllı Türk Ceza Kanunu Gerekçesi

Abadinsky, H. (2010). Organized Crime. Belmont. CA: Wadsworth.

Acaroğlu, O. (2013). Türkiye'de Sigara Kaçakçlığı, Karakteristikler, Kullanılan Yöntemler ve Kaçakçı Profili. Yayınlanmamış Doktora Tezi. Polis Akademisi Güvenlik Bilimleri Enstitüsü.

Albanese, J. (2000). The Causes of Organized Crime: Do Criminals Organize Around Opportunities for Crime or do Criminal Opportunities Create New Offenders?. Journal of Contemporary Criminal Justice. Vol. 16(4). pp.409-423.

Albini, J. (1971). The American Mafia: Genesis of a Legend. New York: Appleton-Century-Crofts.

Beare, M. (1996). Criminal Conspiracies: Organized Crime in Canada. Toronto: University of Toronto Press.

Beirne, P., \& Messerschmidt, J. W. (2006). Criminology. Los Angeles. CA: Roxbury Publishing.

Benson, J. S., \& Decker, S. H. (2010). The Organizational Structure of International Drug Smuggling. Journal of Criminal Justice. Vol.38, pp. 130-138

Block, A. (1983). East Side-westside: Organizing Crime in New York 1930-1950. New Brunswick. NJ: Transaction Publishers.

Block, A., \& Chambliss, W. J. (1981). Organizing Crime. New York/Oxford.

Conklin, J. E. (2010). Criminology. Boston: Pearson. 
Cressey, D. R. (1969). Theft of The Nation: The Structure and Operations of Organized Crime in America. New York: Harper.

Cressey, D. R. (1972). Criminal Organization: Its Elementary Forms. New York: Harper and Row.

Demir, O.Ö. ve Küçükuysal, B. (2011). Sınıraşan Suçlarla Mücadelede Önemli Köşe Taşları: Birleşmiş Milletler Sözleşmeleri, O. Ömer Demir ve Bahadır Küçükuysal (Ed.), Sınıraşan Organize Suçlar: Kavramlar, Yöntemler, Eğilimle. Ankara: Adalet Yayınevi, ss.243-254.

Desroches, F. (2007). Research on Upper Level Drug Trafficking: A Review. Journal of Drug Issues, Vol.37(4). pp.827-844.

Falcone, D. N. (2005). Dictionary of American Criminal Justice \& Criminology. Upper Saddle River, NJ: Pearson Education.

Finckenauer, J. O. (2005). Problems of Definition: What is organized crime?. Trends in Organized Crime. Vol.8(3). Pp. 63-83.

Finckenauer, J. O. (2007). Mafia and Organized Crim. Oxford: Oneworld.

Finckenauer, J, O., (2001). Russian Transational Organized Crime. Global Human Smuggling: Comparative Perspectives, Kyle, D. and Kowslowski, R. (Ed.). Baltimore-London: John Hopkins University Press. pp. 166-186.

Grennan, S., \& Britz, M. T. (2006). Organized Crime: A World Wide Perspective. Upper Saddle River, NJ: Pearson Prentice Hall.

Hagan, F. E. (2010). Crime Types and Criminals. Thousand Oaks. CA: Sage

Hellman, D. A. (1980). Economics of Crime. New York: St. Martin's Press.

Hess, K. (2009). Introduction to Law Enforcement and Criminal Justice. 9th ed., Belmont, CA: Wadsworth

lanni, F. A. J.(1974). Black Mafia: Ethnic Succession in Organized Crime. New York

Kahya, Y. ve Sever, M. (2013). Türkiye'de Göçmen Kaçakçıları. Ankara: Karınca.

Karakaya, M. (2013). Uyuşturucu Madde Ticareti Yapan Suç Örgütlerinin Yapıları ve Suç Faaliyetleri: Erzurum Örneği. Uluslararası Güvenlik ve Terörizm Dergisi. Vol.4(1). pp 43-60.

Karakaya, M. ve Karabal, M. (2012). Organize suç örgütleri profili: Erzurum örneği. IV. Uluslararası Terörizm ve Sınıraşan Suçlar Sempozyumu.

Kenney, D. J., \& Finckenauer, J. O. (1995). Organized Crime in America. Belmont, CA: Wadsworth Pyb. Co. 
Koppen, M. V., Poot, C. J., Kleemans, E. R., \& Nieuwbeerta, P. (2010). Criminal Trajectories in Organized Crime. British Journal of Criminology. Vol. 50. Pp.102-123.

Lupsha, P. A. (1983). Networks versus Networking: Analysis of an Organized Crime Group. G. P. Waldo (ed.). Career Criminals. Beverly Hills, CA: Sage, 59-87.

Maltz, M. D. (1976). On Defining 'Organizedcrime': The Development of a Definition and a Typology. Crime \& Delinquency. Vol.22(3). Pp.338-346.

Mastrofski, S. \& Potter, G. (1986). Evaluating Law Enforcement Efforts to Control Organized Crime: The Pennsylvania Crime Commission as a Case Study. Policy Studies Review, Vol.6(1. Pp.160-170.

Mazzitelli, A. L. (2007). Transnational Organized Crime in West Africa: The Additional Challenge. International Affairs. Vol.83(6). Pp.1071-1090.

Ortmeier, P. J. (2013). Introduction to security: Operations and Management. Upper Saddle River, NJ: Pearson.

Özerkmen, N. ve Kahya, Y. (2008). Organize Suç Örgütlerinin Oluşumunda Hemşehrilik ilişkilerinin Rolü. Polis Bilimleri Dergisi. Vol.4(10. Pp.15-42.

Öztürk, i., Tokat, C. ve Topuksak, B. (2012). Örgütlü Suç Soruşturmaları: Mücadele Yöntem ve Stratejileri. Ankara: Aydoğdu Ofset.

Ponsaers, P., Shapland, J., \& Williams, C, C. (2008). Does the Informal Economy Link to Organized Crime?. International Journal of Social Economic. Vol.35(9). Pp.644-650.

Reuter, P., \& Rubinstein J. B. (1978). Fact, Fancy, and Organized Crime. The Public Interest, Vol.53. pp.45-67

Rhodes, R. P. (1984). Organized Crime: Crime Control vs. Civil Liberties, New York.

Sands, J. (2007). Organized Crime and Illicit Activities in Spain: Causes and Facilitating Factors. Mediterranean Politics. Vol.12(2), pp. 211-232.

Schulte-Bockholt, A. (2001). A neo-marxist Explanation of Organized Crime. Critical Criminology, Vol.10, pp.225-242.

Sellin, T. (1963). Organized Crime as a Business Enterprise. Annals of the American Academy of Political and Social Science, Vol.347, pp.12-19.

Sever, M., (2011). Terörizm ve Sınıraşan Organize Suç ilişkisi. O. Ö, Demir ve B. Küçükuysal (Ed.), Sınıraşan Organize Suçlar: Kavramlar, Yöntemler, Eğilimler. Ankara: Adalet Yayınevi, ss.183221.

UTSAM (2013). Organize Suç Örgütleriyle Eylem ve Eleman Odaklı Mücadele, Ankara: Uluslararası Terörizm ve Sınıraşan Suçlar Araştırma Merkezi (UTSAM) Yayınları. 
Musa KARAKAYA | Yavuz KAHYA

Winslow, R. W., Zhang, S. X. (2008). Criminology: A Global Perspective. Upper Saddle River, NJ: Pearson Prentice Hall.

Yargıtay 8. Ceza Dairesi 2004/11065 E., 2007/517 K. Sayılı Karar

Yargıtay 8. Ceza Dairesi 2005/341 E., 2005/2011 K. Sayılı Kararı 